\title{
Remarkable Imaging Findings of a Migrated Ventriculoperitoneal Shunt: Report of a Case
}

\section{Ventriküloperitoneal Șant Migrasyonunun Ender Görüntüleme Bulgularl: Olgu Sunumu}

\author{
Petek Bayındır1, Edis Çolak1, Kadir Koray Baş2, Hüdaver Alper1 \\ ${ }^{1}$ Ege University Faculty of Medicine, Department of Radiology, Izmir, Turkey \\ 2Kocaeli Derince Education and Research Hospital, Department of General Surgery, Kocaeli, Turkey
}

\begin{abstract}
Ventriculoperitoneal (VP) shunt placement is a common procedure in managing hydrocephalus. One of the rare complications associated with VP shunting is the migration of the catheter to the scrotum. The ultrasonography and plain X-ray findings of an 18 months old boy with the catheter migration to the right hemiscrotum through communicating hydrocele was presented. As far as known, this is a unique case since the imaging findings of a migrated catheter, coiling in the hydrocele sac and repassing through the same inguinal canal to the abdominal cavity are being demonstrated for the first time. Key Words: Cerebrospinal fluid shunts, ventriculoperitoneal (VP) shunt, foreign-body migration, testicular hydrocele
\end{abstract}

\section{Introduction}

Ventriculoperitoneal (VP) shunt insertion is the most common procedure for the management of hydrocephalus. Complications associated with VP shunting are numerous with one of the rarest being the migration of the catheter into the scrotum (1). Here an 18-month-old boy is presented with unique sonography and $\mathrm{X}$-ray findings since the migrated catheter repassing through the same inguinal canal to the abdominal cavity is being demonstrated for the first time.

\section{ÖZET}

Ventriküloperitoneal (VP)şantlar hidrosefalinin tedavisinde en sık kullanılan yöntemdir. VP şant yerleştirme ile ilişkili ve nadir görülen komplikasiyonlardan biri şant kateterin skrotuma migrasiyonudur. Olgumuz 18 aylık erkek çocukta şant kateterin sağ hemiskrotuma migrasiyonun nedeniyle komünike hidroselin gelişmesi ile ilgili ultrasonografik ve direkt radyografik bulguları sunulmaktadır. Bildiğimiz kadarıyla, şant kateterin hidrosel kesesi içinde sarıması ve inguinal kanaldan geçerek karın boşluğuna tekrar girmesini gösteren ender görüntüleme bulguları ilk defa burada gösterilmektedir. Anahtar Kelimeler: Beyin omurilik sıvısı şantları, ventriküloperitoneal şant, yabancı cisim migrasiyonu, testiküler hidrosel

\section{Case Report}

An 18-month-old boy presented with swelling in the right hemiscrotum that had been apparent for 2 weeks. He had undergone VP shunt procedure at the age of 2.5 months due to hydrocephalus as a result of Chiari 2 malformation and spinal meningomyelocele. He had two VP shunt revisions at the age of 7 months and 16 months due to shunt dysfunctions. The swelling was not associated with pain, fever or any signs of intestinal obstruction. Both testicles were descended, palpable in normal positions and there was no history of epididiymitis or orchitis. Laboratory data 
including cell blood count (white blood cell count) and urine analysis were within normal limits and urine culture was reported to be negative.

Scrotal sonography revealed a right sided communicating hydrocele with an echogenic tubular structure within, extending from the peritoneal cavity through the right inguinal canal, then coiling in the hydrocele sac, and heading back to the peritoneal cavity through the same inguinal canal (Figure 1a, 1b). There was also a mild hydrocele on the left hemiscrotum.

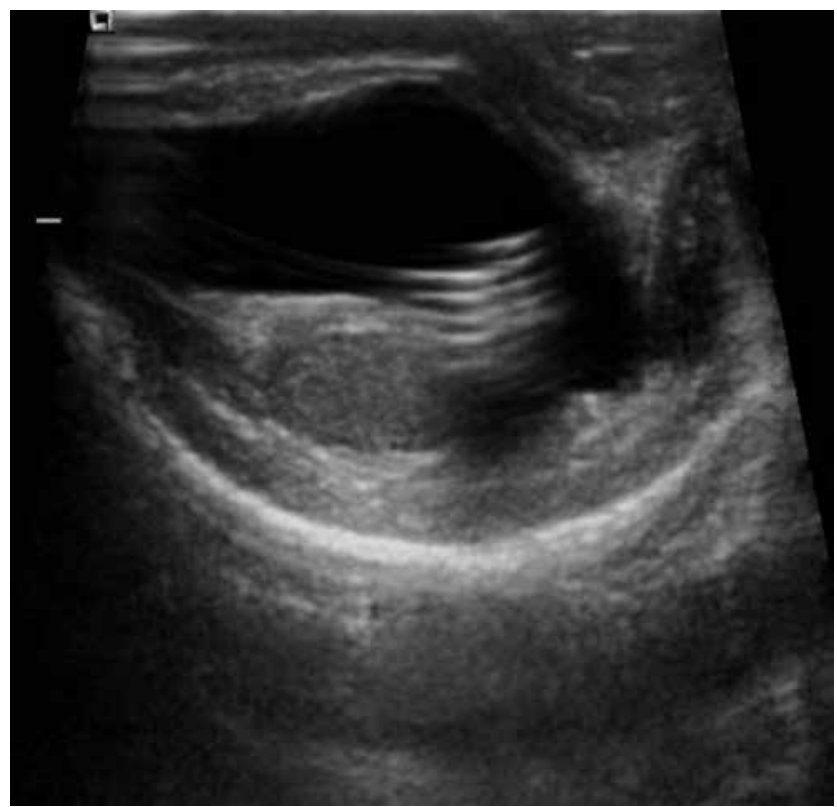

Figure 1a. Scrotal sonogram reveals the coiled echogenic tubuler structure next to the testes in the significant hydrocele in the right hemiscrotum

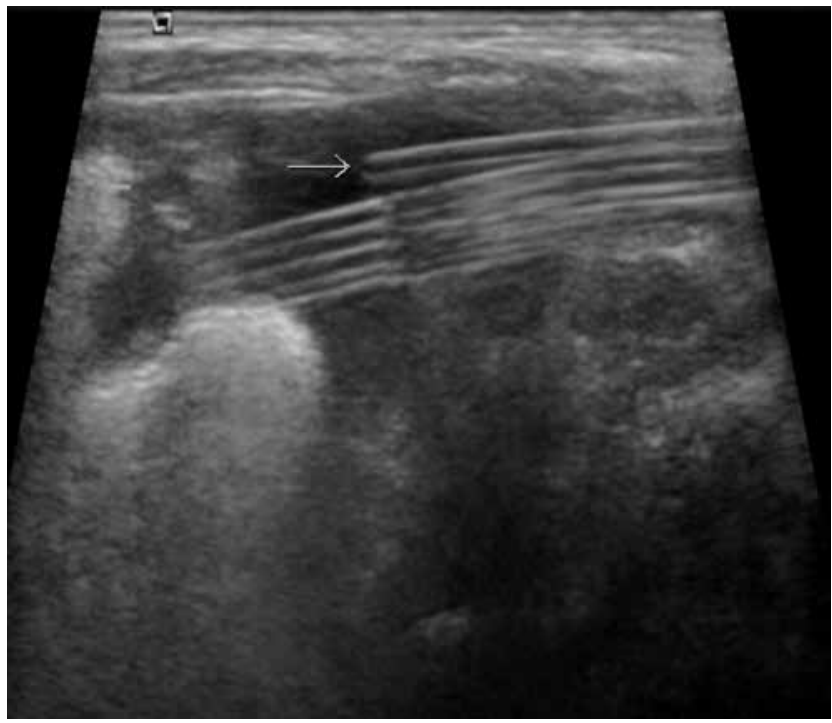

Figure $\mathbf{1 b}$. The peritoneal end of the ascending catheter that has re-passed through the inguinal canal is seen (arrow) next to the descending part of the catheter on the scrotal sonogram
The plain X-ray of the abdomen and pelvis showed the migrated and coiled catheter in the right hemiscrotum and the peritoneal end of the catheter as well (Figure 2a, 2b).

The patient was treated with bilateral hydrocele repair and repositioning of the peritoneal end of the VP shunt

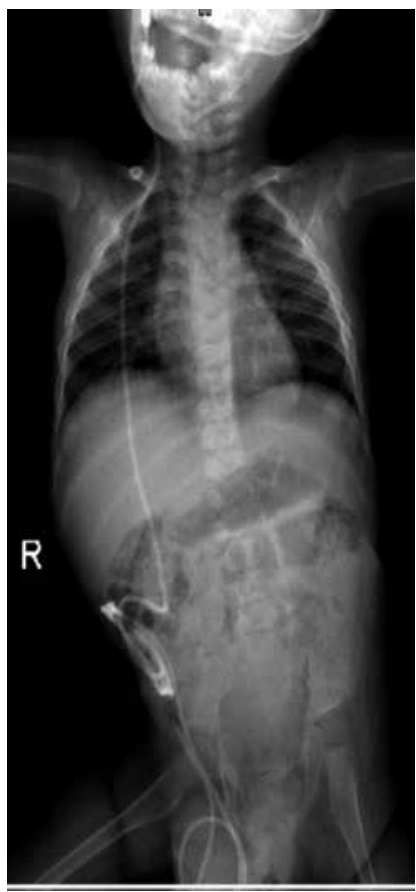

Figure 2a. The descent, coiling and the ascent of the VP shunt into and from the right hemiscrotum is presented on the babygram

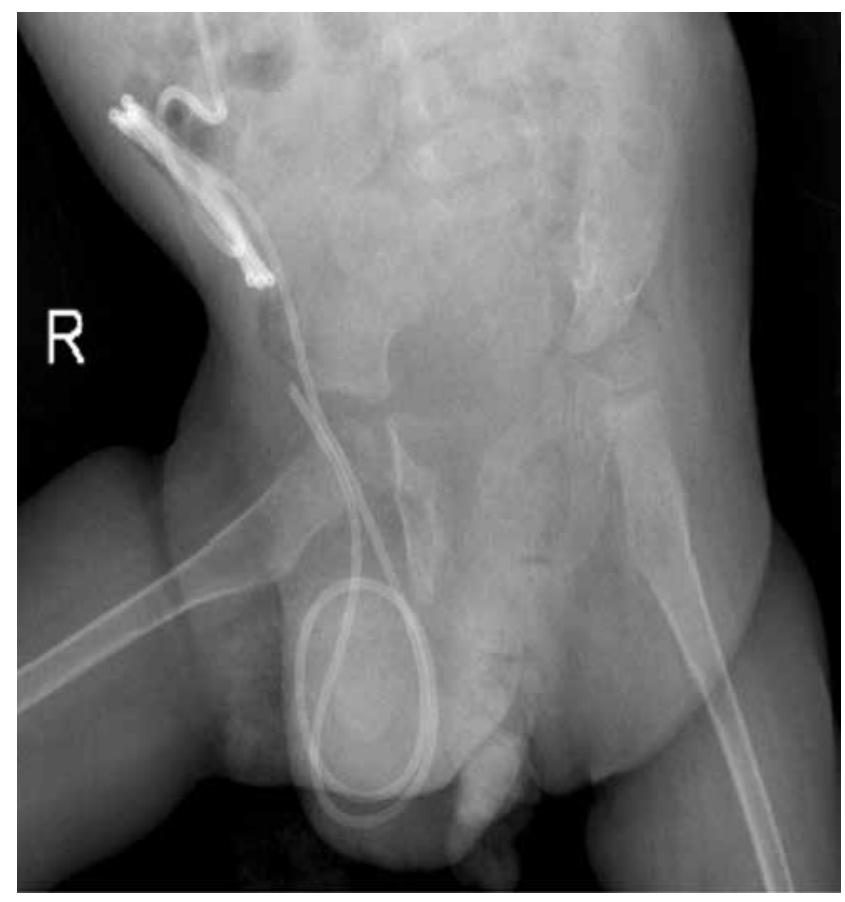

Figure $\mathbf{2 b}$. The pelvic $X$-ray reveals the descent, coiling and the ascent of the VP shunt into and from the right hemiscrotum 
by pediatric surgeons. The surgery was successful and postoperative radiographs confirmed appropriate position of the shunt. The patient was discharged 7 days after the procedure, when his symptoms had subsided. The scrotal sonography prior to discharge showed that the hydrocele volume had decreased. No complications were observed in the 6-month follow-up of our patient.

\section{Discussion}

VP shunt placement is the most common procedure for the management of hydrocephalus. The most common intraabdominal complications of VP shunts are infection, malfunction due to blockage, migration, equipment failure, development of an incisional hernia, subcutaneous collection of cerebrospinal fluid (CSF), and peritoneal pseudocyst formation, whereas perforation of the bladder or bowel, inguinal volvulus of the small intestine, and CSF ascites are rare complications (1).

According to the most recent literature search, migration of the peritoneal catheter into the scrotum has been reported in nearly 30 patients $(2,3)$. Most of them occurred on the right side. In all of the reported cases, imaging findings revealed peritoneal catheters either just entering the scrotum, coiling in the scrotum or a fractured catheter. In none of the reported cases the migrated catheter repassed through the same inguinal canal and reached back to the peritoneal cavity with the sonography and plain X-ray findings as the case presented here.

The greater possibility of a patent processus vaginalis in infants under the age of one year (3) and the smaller size of peritoneal cavity in infancy can be a predisposing factor for VP shunt migration to processus vaginalis $(4,5)$. Our patient was 18 months old during the catheter migration but had been shunted for the last 16 months of his life and the last VP shunt revision procedure due to dysfunction was performed 50 days before. Shunt migration interval after the implantation was compatible with the literature where most of the migrations being stated to occur within the first 6 months of implantation (3). Early implantation and longer duration of the shunt can lead the processus vaginalis to remain patent and the excess fluid in the peritoneal cavity can easily be a causative factor for the occurance of a hydrocele or an inguinal hernia.

Surgical repositioning of the VP shunt and obliteration of the processus vaginalis is the recommended method of surgery to prevent further complications and malfunctioning (3). In our patient, as recommended, surgical repositioning of the abdominal catheter and obliteration of the processus vaginalis during the repair of hydroceles bilaterally was performed by the pediatric surgeons.

In conclusion, as an uncommon complication, VP shunt migration should be kept in mind in infants and children in the case of the enlargement of the scrotum a while after such shunt placements.

Concept: Petek Bayındır, Edis Çolak, Kadir Koray Baş, Hüdaver Alper, Design: Petek Bayındır, Edis Çolak, Kadir Koray Baş, Data Collection or Processing: Petek Bayındır, Analysis or Interpretation: Petek Bayındır, Edis Çolak, Kadir Koray Baş, Literature Search: Petek Bayındır, Writing: Petek Bayındır, Peer-review: Externally peer-reviewed, Conflict of Interest: The authors did not report any conflict of interests regarding this article, Financial Disclosure: No institution or person has received financial support for our work.

\section{References}

1. Chung JJ, Yu JS, Kim JH, Nam SJ, Kim MJ Intraabdominal Complications Secondary to Ventriculoperitoneal Shunts: CT Findings and Review of the Literature. AJR Am J Roentgenol 2009; 193:1311-7.

2. Celik A, Ergün O, Arda MS, Yurtseven T, Erşahin Y, Balik E. The incidence of inguinal complications after ventriculoperitoneal shunt for hydrocephalus. Childs Nerv Syst 2005; 21:44-7.

3. Mohammadi A, Hedayatiasl A, Ghasemi-Rad M. Scrotal migration of a ventriculoperitoneal shunt: a case report and review of literature. Med Ultrason 2012; 14:158-60.

4. Ho CC, Jamaludin WJ, Goh EH, Singam P, Zainuddin ZM. Scrotal mass: A rare complication of Ventriculoperitoneal Shunt. Acta Medica (Hradec Kralove) 2011; 54:81-2.

5. Gupta M, Digra NC, Sharma N, Goyal S, Agrawal A. Migration of the peritoneal catheter of a ventriculoperitoneal shunt into the scrotum. S Afr J CH 2012; 6:93-4. 